\title{
Cerebrovascular function and cognition in childhood: a systematic review of transcranial doppler studies
}

Mireille J Bakker ${ }^{1,2}$, Jessica Hofmann ${ }^{1}$, Owen F Churches ${ }^{3}$, Nicholas A Badcock ${ }^{4}$, Mark Kohler ${ }^{1}$ and Hannah AD Keage ${ }^{1 *}$

\begin{abstract}
Background: The contribution of cerebrovascular function to cognitive performance is gaining increased attention. Transcranial doppler (TCD) is portable, reliable, inexpensive and extremely well tolerated by young and clinical samples. It enables measurement of blood flow velocity in major cerebral arteries at rest and during cognitive tasks.

Methods: We systematically reviewed evidence for associations between cognitive performance and cerebrovascular function in children (0-18 years), as measured using TCD. A total of 2778 articles were retrieved from Psychlnfo, Pubmed, and EMBASE searches and 25 relevant articles were identified.

Results: Most studies investigated clinical groups, where decreased blood flow velocities in infants were associated with poor neurological functioning, and increased blood flow velocities in children with Sickle cell disease were typically associated with cognitive impairment and lower intelligence. Studies were also identified assessing autistic behaviour, mental retardation and sleep disordered breathing. In healthy children, the majority of studies reported cognitive processing produced lateralised changes in blood flow velocities however these physiological responses did not appear to correlate with behavioural cognitive performance.

Conclusion: Poor cognitive performance appears to be associated with decreased blood flow velocities in premature infants, and increased velocities in Sickle cell disease children using TCD methods. However knowledge in healthy samples is relatively limited. The technique is well tolerated by children, is portable and inexpensive. It therefore stands to make a valuable contribution to knowledge regarding the underlying functional biology of cognitive performance in childhood.
\end{abstract}

Keywords: Cognition, Infants, Children, Adolescents, Transcranial doppler, Cerebrovascular

\section{Background}

The neural underpinnings of cognition have received a great deal of attention in the developmental literature. Neuronal activity is coupled with blood supply in the brain [1], and given this, the role of cerebrovascular function in relation to cognitive function in childhood is an important consideration [2-4]. Cerebrovascular function in childhood has been investigated using a variety of techniques such as functional magnetic resonance imaging (fMRI), positron emission tomography (PET) and

\footnotetext{
* Correspondence: Hannah.Keage@unisa.edu.au

${ }^{1}$ Cognitive Neuroscience Laboratory, School of Psychology, Social Work and Social Policy, University of South Australia, GPO BOX 2471, 5001 Adelaide, SA, Australia

Full list of author information is available at the end of the article
}

near infrared spectroscopy (NIRS). However, these techniques are expensive and there are feasibility issues which are particularly problematic in child samples, including requirements of sitting or lying still for a prolonged duration [5].

Recently, Transcranial Doppler (TCD) ultrasonography has been increasingly employed as a non-invasive, inexpensive, safe and portable technique for measuring cerebrovascular function. It permits continuous and bilateral recording of cerebral blood flow velocity through the major intracranial vessels (middle, anterior, posterior and basilar arteries), is relatively resistant to movement artefact, has good test-retest reliability [4], and is a suitable technique for child samples $[3,4,6,7]$. Further, given that the skull is relatively thin in childhood (most 
notably around the temporal window), blood vessels are easily insonated and failure to detect a signal is rare, unlike in aged populations where skull thickness can impede recording in around 30 percent of cases [8]. Measurements can be taken at rest and during cognitive tasks. TCD data collected during cognitive operations is referred to as functional TCD (fTCD), and is a calculation of the average increase in blood flow velocity (over multiple trials) relative to a specific mental operation [9].

Given that the contribution of cerebrovascular function to cognition is important and that the technique is well suited to child populations, we aimed to systematically review the literature to assess how TCD measures relate to cognitive performance in childhood. In doing so, we wanted to highlight measures which appear to correlate with cognitive performance (and those which do not), and point to key areas of future research.

\section{Methods}

\section{Review criteria}

Primary and secondary screens of the literature were performed. A primary screen, including PubMed, Embase, and PsycINFO searches, was conducted for peer-reviewed papers published between January 1970 and 31 May 2013. The following search terms were employed in the primary screen: (ultrasonography doppler transcranial OR TCD OR transcranial doppler*) AND (baby OR newborn* OR infant* OR preschool* OR teenager* OR child* OR adoles*). A total of 2778 articles were retrieved.

Titles and abstracts were read by at least two of the authors (MJB, JH or HADK). Articles were retained if they collected TCD data at rest or during a cognitive task, from any cerebral artery accessible via TCD (e.g. anterior, middle, posterior or basilar) and where the mean age of participants was less than or equal to 18 years of age. Bibliographies from the identified articles were also manually searched for relevant publications. Articles were excluded if they were not written in English, were a case-report, or did not look at the statistical association between a TCD measure and a measure of cognitive performance. Preferred Reporting Items for Systematic Reviews and Meta-Analyses (PRISMA) guidelines were followed [10].

\section{Data extraction}

If the article was included, the following data was extracted: participant characteristics (i.e. number, age range or mean if unavailable, male/female ratio, clinical diagnosis if applicable), TCD protocol and vessel, cognitive measure, and relevant findings (linking TCD and cognition results).

\section{Results}

Twenty-five peer-reviewed research articles were eligible for this review, representing data from 1693 participants. Publication dates ranged from 1 January 1991 to 31 May 2013. A flow diagram of study identification is shown in Figure 1. Methodological characteristics of each study are summarized in Table 1 and include: study sample (including sex, age and diagnoses), TCD protocol and vessel(s) investigated, cognitive measure, and key finding (i.e., those that relate to an association between a cognitive measure and a TCD measure). The calculation of common resting TCD measures employed in identified studies are summarised in Figure 2 including: systolic peak flow velocity (SV), end diastolic velocity (DV), mean flow velocity (MV), the pulsatility index (PI), and resistance index (RI). The fTCD evoked-flow response, and resultant measures, is also displayed in Figure 2.

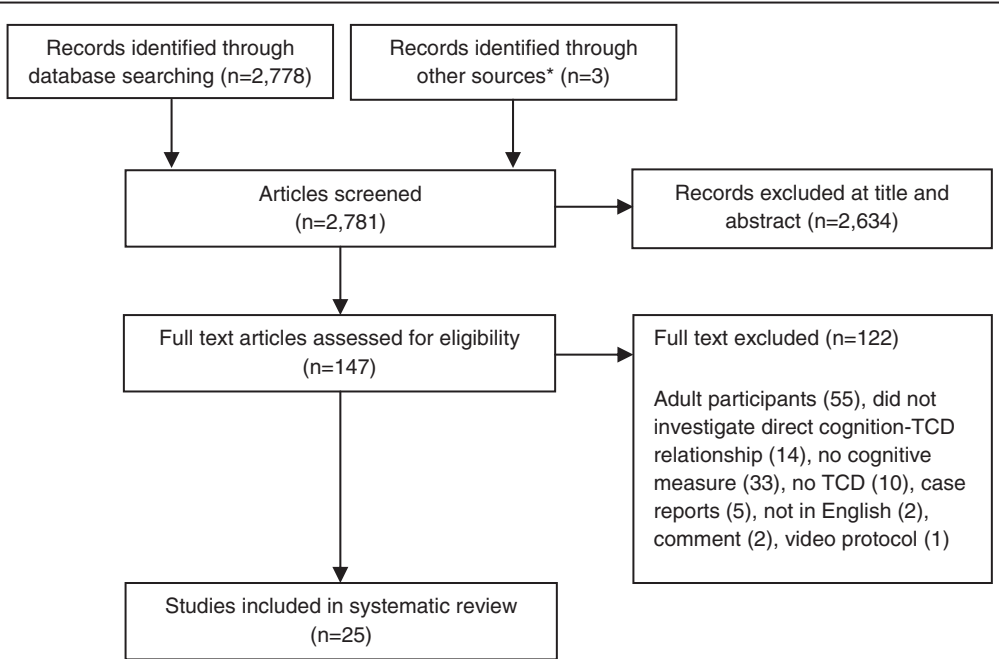

Figure 1 Preferred Reporting Items for Systematic Reviews and Meta-Analyses (PRISMA) flow diagram of study identification. ${ }^{*}$ Through references of manual search. 
Table 1 Summary of the articles using resting and functional/cognitive TCD measures to investigate the association between blood flow velocity and cognition in children

\begin{tabular}{|c|c|c|c|c|c|}
\hline Article & $\begin{array}{l}\text { Participants v controls } \\
\text { (if applicable) }\end{array}$ & $\begin{array}{l}\text { Total N (subgroups)/mean age } \\
\text { (sd)/\% males }\end{array}$ & TCD protocol and vessel(s) & Cognitive measure & Relevant findings \\
\hline \multicolumn{6}{|c|}{ RESTING TCD STUDIES } \\
\hline \multicolumn{6}{|l|}{ In infants } \\
\hline \multirow[t]{2}{*}{ Rennie et al. [13] } & \multirow{2}{*}{$\begin{array}{l}\text { Low birth weight infants with } \\
\text { developmental delay }(\mathrm{DD}) \mathrm{v} \\
\text { normal development infants }\end{array}$} & \multirow{2}{*}{$\begin{array}{l}n=74(D D n=9 \text {, control } n=42) / \\
\text { mean gestational age weeks DD } \\
27(S D=1) \text {, control } 29(S D=2) / \\
\text { DD } 67 \% \text { male, control } 50 \% \text { male }\end{array}$} & $\begin{array}{l}\text { Resting TCD; MV recorded } \\
\text { over first } 3 \text { days of life }\end{array}$ & \multirow[t]{2}{*}{$\begin{array}{l}\text { BSID (mental development) } \\
\text { taken at } 18 \text { months of age. }\end{array}$} & \multirow{2}{*}{$\begin{array}{l}\text { DD infants less likely to show the usual } \\
\text { steady increase in SV. A larger percentage } \\
\text { (44\%) of DD infants displayed a rise, then } \\
\text { a fall, in CBFV compared to infants in the } \\
\text { control group (13\%). }\end{array}$} \\
\hline & & & Unilateral ACA & & \\
\hline \multirow[t]{3}{*}{ Ojala et al. [12] } & \multirow{3}{*}{$\begin{array}{l}\text { Ventilated preterm infants } \\
\text { with RDS (V-RDS) and } \\
\text { non-ventilated preterm } \\
\text { infants with no signs of } \\
\text { RDS (N-RDS) }\end{array}$} & \multirow{3}{*}{$\begin{array}{l}n=49(\mathrm{~V}-\mathrm{RDS} \mathrm{n}=35, \mathrm{~N}-\mathrm{RDS} \\
\mathrm{n}=14) / \mathrm{N} \text {-RDS mean gestational } \\
\text { age } 29 \text { weeks }(\mathrm{SD}=1), \mathrm{N} \text {-RDS } \\
\text { mean gestational age } 31 \text { weeks } \\
(\mathrm{SD}=1) \mathrm{N} \text {-RDS } 57 \% \text { males, } \\
\mathrm{N} \text {-RDS } 57 \% \text { male }\end{array}$} & \multirow{2}{*}{$\begin{array}{l}\text { Resting TCD; SV, DV, MV and } \\
\text { RI taken at } 6,12 \text {, and } 24 \text { hours } \\
\text { post-birth }\end{array}$} & 10-min Apgar score. & \multirow{3}{*}{$\begin{array}{l}\text { In N-RDS group, lower RI was associated } \\
\text { with poorer neurologic results at } 12 \text { month } \\
\text { No association in V-RDS group. }\end{array}$} \\
\hline & & & & \multirow{2}{*}{$\begin{array}{l}\text { GMDS (physical and mental } \\
\text { development) at } 12 \text { months. }\end{array}$} & \\
\hline & & & Unilateral ACA & & \\
\hline \multirow[t]{3}{*}{ Arditi et al. [11] } & \multirow[t]{3}{*}{ Premature infants } & \multirow{3}{*}{$\begin{array}{l}\mathrm{n}=51 / \text { mean gestational age } \\
\text { weeks } 30(\mathrm{SD}=3) / 53 \% \text { male }\end{array}$} & Resting TCD; SV, DV and MV & \multirow{2}{*}{$\begin{array}{l}\text { NBAS (visual/auditory } \\
\text { habituation) at } 37 \text { weeks } \\
\text { gestational age. }\end{array}$} & \multirow{3}{*}{$\begin{array}{l}\text { Greater right SV related to lower neonatal } \\
\text { performance on the NBAS. Greater left SV } \\
\text { related to high MDI scores at } 24 \text { months. } \\
\text { Left }>\text { right SV related to better neonatal } \\
\text { orientation and high MDI scores at } \\
24 \text { months. }\end{array}$} \\
\hline & & & Bilateral MCA & & \\
\hline & & & & $\begin{array}{l}\text { BSID-II (mental development) } \\
\text { at } 6,12 \text {, and } 24 \text { months. }\end{array}$ & \\
\hline \multirow[t]{3}{*}{ Scherjon et al. [14] } & \multirow[t]{3}{*}{ Premature infants } & \multirow[t]{3}{*}{$\begin{array}{l}n=123 / \text { mean gestational age } \\
31 \text { weeks/sex not reported }\end{array}$} & \multirow{2}{*}{$\begin{array}{l}\text { Resting TCD; MV and MV ratio } \\
\text { (defined as MV during the first } \\
12 \text { hours after birth, divided by } \\
\text { mean velocity in the period } \\
\text { 12-hours post-birth) }\end{array}$} & $\begin{array}{l}\text { Prechtl score (neurological } \\
\text { functioning) at } 40 \text { weeks } \\
\text { corrected gestational age. }\end{array}$ & \multirow{3}{*}{$\begin{array}{l}\text { Prechtl scores were related to MV } \\
\text { ratio - high Prechtl score related to low } \\
\text { MV ratio (reflecting MV not increasing } \\
\text { over first days of life). No relationships } \\
\text { between Touwen scores and TCD } \\
\text { measures. }\end{array}$} \\
\hline & & & & \multirow{2}{*}{$\begin{array}{l}\text { Touwen score (neurological } \\
\text { functioning) at ages } 6 \text { and } \\
12 \text { months. }\end{array}$} & \\
\hline & & & MCA & & \\
\hline \multirow[t]{2}{*}{ Alatas et al. [15] } & \multirow{2}{*}{$\begin{array}{l}\text { Infants from HRP mothers } \\
\checkmark \text { infants from normal } \\
\text { pregnancy mothers }\end{array}$} & \multirow{2}{*}{$\begin{array}{l}n=237(\text { HRP } n=75 \text {, control } \\
n=162) / \text { mean gestational } \\
\text { age at delivery HRP } 38 \text { weeks, } \\
\text { control } 39 \text { weeks/sex } \\
\text { not reported }\end{array}$} & $\begin{array}{l}\text { In-utero from } 24 \text { weeks } \\
\text { gestation until delivery }\end{array}$ & \multirow{2}{*}{$\begin{array}{l}1 \text { and } 5 \text {-minute Apgar scores } \\
\text { (general and neurological } \\
\text { functioning). }\end{array}$} & \multirow{2}{*}{$\begin{array}{l}\text { Positive relationship between MCA PI } \\
\text { and } 5 \text {-min Apgar scores in infants from } \\
\text { HRP; no relationship in control group. }\end{array}$} \\
\hline & & & MCA & & \\
\hline \multicolumn{6}{|l|}{ In Sickle Cell Disease } \\
\hline \multirow[t]{2}{*}{ Hogan et al. [19] } & \multirow[t]{2}{*}{$\begin{array}{l}\text { Infants with SCD v } \\
\text { healthy infants }\end{array}$} & \multirow[t]{2}{*}{$\begin{array}{l}n=28(S C D n=14, \text { control } n=12) / \\
\text { between } 1-13 \text { months/SCD } 79 \% \\
\text { male, control } 42 \% \text { male }\end{array}$} & $\begin{array}{l}\text { Resting TCD; SV and MV } \\
\text { recorded at ages } 3,9 \text { and } \\
12 \text { months }\end{array}$ & \multirow[t]{2}{*}{$\begin{array}{l}\text { BINS (neurological function) } \\
\text { taken at 3,9 and } 12 \text { months. }\end{array}$} & \multirow{2}{*}{$\begin{array}{l}\text { Infants with SCD had increased SV and } \\
\text { MV, which were associated with a } \\
\text { higher risk of neurodevelopmental } \\
\text { delay at } 9 \text { months of age (not } 3 \\
\text { or } 12 \text { months). }\end{array}$} \\
\hline & & & BA, bilateral MCA and ICA & & \\
\hline \multirow[t]{2}{*}{ Armstrong et al. [30] } & Infants with SCD & $n=208 /$ mean age 13 months & Resting TCD; SV & BSID-II (mental, motor and & Lower VABS scores (communications, \\
\hline & & & Vessel not specified & $\begin{array}{l}\text { behavioural development), } \\
\text { VABS (developmental status } \\
\text { based on parent report). }\end{array}$ & $\begin{array}{l}\text { daily living skills and socialisation } \\
\text { domains) were associated with } \\
\text { greater SV. No association between } \\
\text { SV and BSID-II. }\end{array}$ \\
\hline
\end{tabular}


Table 1 Summary of the articles using resting and functional/cognitive TCD measures to investigate the association between blood flow velocity and cognition in children (Continued)

\begin{tabular}{|c|c|c|c|c|c|}
\hline \multirow[t]{3}{*}{ Schatz et al. [25] } & \multirow[t]{3}{*}{ Children with SCD } & \multirow{2}{*}{$\begin{array}{l}n=50 / \text { mean age } 26 \text { months } \\
(S D=13) / 56 \% \text { male }\end{array}$} & Resting TCD; MV & \multirow{3}{*}{$\begin{array}{l}\text { DDST-II (infant and } \\
\text { childhood development). } \\
\text { VABS (developmental status } \\
\text { based on parent report) }\end{array}$} & \multirow{3}{*}{$\begin{array}{l}\text { Children with developmental delays } \\
\text { had significantly higher MCA MVs, } \\
\text { compared typically developing } \\
\text { children (all with SCD). }\end{array}$} \\
\hline & & & \multirow[t]{2}{*}{ Bilateral ICA and MCA } & & \\
\hline & & $\begin{array}{l}\text { Note: TCD in an } \mathrm{n}=30 \\
\text { subsample }\end{array}$ & & & \\
\hline \multirow[t]{2}{*}{ Aygun et al. [16] } & \multirow[t]{2}{*}{ Children with SCD } & \multirow{2}{*}{$\begin{array}{l}\mathrm{n}=88 / \text { mean age } 4 \text { years } \\
(\mathrm{SD}<1) / 51 \% \text { male }\end{array}$} & Resting TCD; MV & \multirow{2}{*}{$\begin{array}{l}\text { BPS-II (motor, language and } \\
\text { cognitive development). }\end{array}$} & \multirow{2}{*}{$\begin{array}{l}\text { No association was found between TCD } \\
\text { measures and cognitive performance. }\end{array}$} \\
\hline & & & $\begin{array}{l}\text { BA, bilateral MCA, ACA, PCA } \\
\text { and ICA }\end{array}$ & & \\
\hline \multirow[t]{2}{*}{ Sanchez et al. [24] } & \multirow[t]{2}{*}{ Children with SCD } & \multirow{2}{*}{$\begin{array}{l}n=39 / \text { mean age } 6 \text { years } \\
(S D=1) / 41 \% \text { male }\end{array}$} & Resting TCD; SV & TOLD-P:3 (language ability). & \multirow{2}{*}{$\begin{array}{l}\text { Higher SVs were associated with poorer } \\
\text { syntactical ability. }\end{array}$} \\
\hline & & & Bilateral MCA & WJ-III (academic achievement). & \\
\hline \multirow[t]{2}{*}{ Strouse et al. [26] } & \multirow[t]{2}{*}{ Children with SCD } & \multirow{2}{*}{$\begin{array}{l}n=24 / \text { mean age } 9 \text { years } \\
(S D=2) / \text { sex not reported }\end{array}$} & Resting TCD; SV & \multirow[t]{2}{*}{ WASI (IQ). } & \multirow{2}{*}{$\begin{array}{l}\text { No significant correlation between SV } \\
\text { and IQ. }\end{array}$} \\
\hline & & & Bilateral ACA & & \\
\hline \multirow[t]{3}{*}{ Onofri et al. [31] } & \multirow[t]{3}{*}{ Children with SCD } & \multirow{3}{*}{$\begin{array}{l}\mathrm{n}=35 / \text { mean age } 9 \text { years } \\
(\mathrm{SD}=3) / 49 \% \text { male }\end{array}$} & Resting TCD; SV & \multirow{2}{*}{$\begin{array}{l}\text { WISC-II (IQ) for children } \\
\text { aged 6-16 years. }\end{array}$} & \multirow{3}{*}{$\begin{array}{l}\text { There were no differences between } \\
\text { mentally impaired and non-impaired } \\
\text { groups in those terms of percentage } \\
\text { with abnormal SV. }\end{array}$} \\
\hline & & & $\begin{array}{l}\text { Abnormal SV defined } \\
\text { as }>170 \mathrm{~cm} / \mathrm{s}\end{array}$ & & \\
\hline & & & Vessel unspecified & $\begin{array}{l}\text { WPPSI-III (IQ) for children } \\
\text { aged 4-6 years. }\end{array}$ & \\
\hline \multirow[t]{6}{*}{ Kral et al. [22] } & \multirow[t]{6}{*}{ Children with SCD } & \multirow{6}{*}{$\begin{array}{l}n=60 / \text { mean age } 121 \text { months } \\
(S D=31) / 43 \% \text { male }\end{array}$} & Resting TCD; SV & WASI (IQ). & \multirow{6}{*}{$\begin{array}{l}\text { Children with abnormal TCD had lower } \\
\text { verbal IQs than children with conditional } \\
\text { TCD. Children with conditional TCD } \\
\text { performed worse than children with } \\
\text { normal TCD on measures of executive } \\
\text { function. The conditional TCD group } \\
\text { was slowest to complete the TMT. }\end{array}$} \\
\hline & & & Abnormal TCD defined as & WJ-R (academic achievement). & \\
\hline & & & TCD defined as SV $=170-200$ & $\begin{array}{l}\text { CPT-II (visual sustained } \\
\text { attention). }\end{array}$ & \\
\hline & & & as SV $<170 \mathrm{~cm} / \mathrm{sec}$ & CMS (working memory). & \\
\hline & & & Bilateral MCA and ICA & TMT (visual attention). & \\
\hline & & & & BRIEF (executive functioning). & \\
\hline \multirow[t]{3}{*}{ Kral and Brown [20] } & \multirow[t]{3}{*}{ Children with SCD } & \multirow{3}{*}{$\begin{array}{l}n=62 / \text { mean age } 121 \text { months } \\
(S D=31) / 43 \% \text { male }\end{array}$} & Resting TCD; MV & Academic attainment; grade & Children with abnormal TCD received \\
\hline & & & $\begin{array}{l}\text { Abnormal TCD defined as } \\
S V>200 \mathrm{~cm} / \mathrm{sec}\end{array}$ & $\begin{array}{l}\text { retention and special } \\
\text { education placement. }\end{array}$ & $\begin{array}{l}\text { significantly more special education } \\
\text { services. }\end{array}$ \\
\hline & & & Bilateral MCA and ICA & & \\
\hline Kral et al. [21] & Children with SCD & $n=27 /$ mean age 129 months & Resting TCD; MV & WASI (IQ). & When controlled for age and hematocrit, \\
\hline & & $(\mathrm{SD}=36) / 44 \%$ male & Abnormal TCD defined as & WJ-R (academic achievement). & $\begin{array}{l}\text { children with abnormal ICD had better } \\
\text { verbal memory in comparison to children }\end{array}$ \\
\hline & & & $\begin{array}{l}\mathrm{SV}>200 \mathrm{~cm} / \mathrm{sec} \text {; normal } \mathrm{CD} \\
\text { defined as } \mathrm{SV}<170 \mathrm{~cm} / \mathrm{sec}\end{array}$ & CPT-II (sustained attention), & with normal TCD. \\
\hline & & & Bilateral MCA, ACA and ICA & CMS (working memory). & \\
\hline & & & & TMT (visual attention). & \\
\hline & & & & $\begin{array}{l}\text { Academic attainment; grade } \\
\text { retention and special } \\
\text { education placement. }\end{array}$ & \\
\hline & & & & DTVMI (visuo-motor integration). & \\
\hline
\end{tabular}


Table 1 Summary of the articles using resting and functional/cognitive TCD measures to investigate the association between blood flow velocity and cognition in children (Continued)

\begin{tabular}{|c|c|c|c|c|c|}
\hline \multirow[t]{4}{*}{ Hijmans et al. [18] } & \multirow[t]{4}{*}{ Children with severe SCD } & \multirow{4}{*}{$\begin{array}{l}\mathrm{n}=37 / \text { mean age } 12 \text { years } \\
(\mathrm{SD}=3) / 53 \% \text { male }\end{array}$} & \multirow{2}{*}{$\begin{array}{l}\text { Resting TCD; MV (within } \\
14 \text { months preceding } \\
\text { neurocognitive testing) }\end{array}$} & WISC-III/WAIS-III (IQ), & \multirow{4}{*}{$\begin{array}{l}\text { No associations between TCD and cognitive } \\
\text { measures. However, sustained attention } \\
\text { better in children with right > left resting MV. }\end{array}$} \\
\hline & & & & $\begin{array}{l}\text { Stop task (response } \\
\text { inhibition and sustained }\end{array}$ & \\
\hline & & & \multirow[t]{2}{*}{ Bilateral MCA, ACA and ICA } & $\begin{array}{l}\text { attention), Tower of } \\
\text { London (planning), }\end{array}$ & \\
\hline & & & & $\begin{array}{l}\text { N-back task; (working } \\
\text { memory). }\end{array}$ & \\
\hline \multirow{4}{*}{$\begin{array}{l}\text { Bernaudin et al. } \\
\text { [17] }\end{array}$} & \multirow{4}{*}{$\begin{array}{l}\text { Children with SCD v } \\
\text { siblings without SCD }\end{array}$} & \multirow{3}{*}{$\begin{array}{l}n=249(S C D n=173, \text { control } \\
n=76) / \text { mean age SCD } 10 \text { years } \\
(S D=3) \text {, not reported for } \\
\text { controls } / S C D 51 \% \text { male, } \\
\text { controls not reported }\end{array}$} & Resting TCD; SV, DV and MV & \multirow[t]{4}{*}{ WISC-II/WPPSI-R (IQ). } & \multirow{2}{*}{$\begin{array}{l}\text { SCD sample: children with abnormal TCD } \\
\text { had lower IQ scores (picture arrangement } \\
\text { and performance IQ). }\end{array}$} \\
\hline & & & $\begin{array}{l}\text { Abnormal TCD defined as } \\
\text { SV > } 200 \mathrm{~cm} / \mathrm{sec}\end{array}$ & & \\
\hline & & & \multirow{2}{*}{$\begin{array}{l}\text { BA, bilateral MCA, ACA, PCA, } \\
\text { and ICA }\end{array}$} & & \multirow{2}{*}{$\begin{array}{l}\text { Effect did not hold after excluding those } \\
\text { with stroke. }\end{array}$} \\
\hline & & $\begin{array}{l}\text { TCD only collected on a } \mathrm{n}=143 \\
\text { subsample }\end{array}$ & & & \\
\hline \multirow[t]{4}{*}{ Ruffieux et al. [23] } & \multirow[t]{4}{*}{ Children with SCD } & \multirow{4}{*}{$\begin{array}{l}n=32 / \text { between } 6 \text { and } 24 \text { years } \\
\text { of age/48\% male }\end{array}$} & Resting TCD; SV and DV & \multirow{2}{*}{$\begin{array}{l}\text { CVLT (memory). Executive } \\
\text { function/attention tasks } \\
\text { including }\end{array}$} & \multirow{3}{*}{$\begin{array}{l}\text { Children with A-TCD had worse memory } \\
\text { performance, as compared to children } \\
\text { with N-TCD measurements. }\end{array}$} \\
\hline & & & \multirow{2}{*}{$\begin{array}{l}\text { Normal }(\mathrm{N}-\mathrm{TCD}) \text { defined as } \\
\text { max. velocity }<170 \mathrm{~cm} / \mathrm{sec} \text {; } \\
\text { abnormal }(\mathrm{A}-\mathrm{TCD}) \text { defined } \\
\text { as max. velocity }>200 \mathrm{~cm} / \mathrm{sec} \\
\text { or peak systolic } \geq 250 \mathrm{~cm} / \mathrm{sec}\end{array}$} & & \\
\hline & & & & $\begin{array}{l}\text { Colour trails, digit span, } \\
\text { coding, verbal semantic } \\
\text { fluency test, bell cancellation } \\
\text { task, letter-number } \\
\text { sequencing and CPT. }\end{array}$ & \\
\hline & & & $\mathrm{OA}, \mathrm{MCA}, \mathrm{ACA}, \mathrm{BA}, \mathrm{ICA}$ & & \\
\hline \multicolumn{6}{|c|}{ In sleep disordered breathing } \\
\hline \multirow[t]{3}{*}{ Hill et al. [17] } & \multirow{3}{*}{$\begin{array}{l}\text { Children with mild SDB } v \\
\text { healthy control children }\end{array}$} & \multirow{3}{*}{$\begin{array}{l}n=31(S D B n=21, \text { control } \\
n=17) / \text { mean age SBD } 6 \text { years } \\
(S D=1), \text { control } 5 \text { years } \\
(S D=1) / S D B 43 \% \text { male, } \\
\text { control } 53 \% \text { male }\end{array}$} & Resting TCD; SV, MV & WPPSI-III (IQ). & \multirow{3}{*}{$\begin{array}{l}\text { CBFV significantly increased in the SDB } \\
\text { group, as compared to controls. SDB } \\
\text { children achieved lower scores on } \\
\text { processing speed and visual attention, } \\
\text { but no direct association with CBFV. }\end{array}$} \\
\hline & & & Bilateral MCA & $\begin{array}{l}\text { NEPSY (neuropsychological } \\
\text { development). }\end{array}$ & \\
\hline & & & & BRIEF (executive functioning). & \\
\hline \multicolumn{6}{|l|}{ FTCD STUDIES } \\
\hline \multicolumn{6}{|l|}{ In clinical groups } \\
\hline \multirow[t]{2}{*}{ Bruneau et al. [27] } & \multirow{2}{*}{$\begin{array}{l}\text { Children with autistic } \\
\text { behaviour }(\mathrm{AB}) \text {, mentally } \\
\text { retarded children without } \\
\text { autistic symptoms (MR) and } \\
\text { healthy control children }\end{array}$} & \multirow{2}{*}{$\begin{array}{l}\mathrm{n}=34(\mathrm{AB} \mathrm{n}=12, \mathrm{MR} \mathrm{n}=10 \\
\text { control } \mathrm{n}=12) / \text { mean age } \mathrm{AB} \\
7 \text { years }(\mathrm{SD}=<1) \text {, MR } 6 \text { years } \\
(\mathrm{SD}<1) \text {, control } 7 \text { years }(\mathrm{SD}<1) / \\
\mathrm{AB} 67 \% \text {, MR } 70 \% \text {, control } \\
33 \% \text { male }\end{array}$} & $\begin{array}{l}\text { fTCD using auditory stimuli } \\
\text { (passive task); SV, DV, MV and RI }\end{array}$ & Auditory tone stimuli & \multirow{2}{*}{$\begin{array}{l}\text { Auditory stimulation increased velocities } \\
\text { and decreased RI on the left side for the } \\
\text { control children. Same pattern for MR } \\
\text { children, but less asymmetrical. AB } \\
\text { children displayed a symmetric and } \\
\text { opposite pattern, with velocities decreasing } \\
\text { and RI increasing on both sides. }\end{array}$} \\
\hline & & & Bilateral MCA & & \\
\hline
\end{tabular}


Table 1 Summary of the articles using resting and functional/cognitive TCD measures to investigate the association between blood flow velocity and cognition in children (Continued)

\section{In typically developing children \\ Stroobant et al. [32] Typically developing children $n=26 /$ mean age 82 months/ $46 \%$ male}

Lohmann et al. [4] Typically developing children $n=10 / 2-10$ years of age/

Groen et al. [2]

\begin{abstract}
Typically developing children $n=14 /$ mean age 7 years
\end{abstract}
Groen et al. [3] Typically developing children $n=60 / 6-16$ years of

Haag et al. [28]

$$
\begin{aligned}
& \text { Typically developing right } \\
& \text { handed children }
\end{aligned}
$$
$40 \%$ male $(\mathrm{SD}<1) / 57 \%$ male age $/ 43 \%$ male

fTCD using visual stimuli requiring expressive response, and auditory stimuli requiring no response; MV and calculated $\mathrm{LI}$ (left-right MV in respons to stimuli)

Bilateral MCA

fTCD with a picture description task: MV and calculating L (left-right MV in response to stimuli)

Bilateral MCA

fTCD using visual stimuli requiring a physical response; MV and calculated LI (left-right MV in response to stimuli)

Bilateral MCA

fTCD using visual stimuli requiring a verbal and physical response; MV and calculated $\mathrm{LI}$ (left-right MV in response to stimuli)

Bilateral MCA

\section{fTCD using visual stimuli} requiring a verbal response; $\mathrm{MV}$ and calculated LI (left-right MV in response to stimuli) adolescents $n=22$ )/mean age children 8 years $(S D=2)$ adolescents 15 years $(S D=2)$ / children $48 \%$ males, adolescents 36\% males
Taaltest voor kinderen/ "language tests for children" (language development)

The expressive language task elicited a stronger left $\mathrm{LI}$ than the passive language task. Good test-retest reliability for TCD. No relationship between $\mathrm{LI}$ and Dutch language test.

Illinois Test of Psycholinguistic Left lateralised increased in blood flow Abilities velocity (i.e. positive lateralisation index), however this did not relate to language ability

Rabbits paradigm (visuospatial memory)

A negative $\mathrm{LI}$ was found, indicating right lateralisation. Task performance unrelated to LI.

LIPS-R (performance IQ).

Most children (58\%) were left lateralised for language, and right lateralised for BPVS-2 (receptive vocabulary). visuospatial memory. Children with left TOWRE (reading). NEPSY (phonological short-term memory). lateralisation language had better vocabulary and non-word reading performance (independent of laterality of visuospatial memory).

Visual stimuli.

Children completed a

non-lexical picture

description task. Adolescents

additionally completed a

lexical word genpleted a

Vessels: ACA Anterior cerebral artery, BA Basilar artery, ICA Internal cerebral artery, MCA Middle cerebral artery, OA Ophthalmic artery, PCA Posterior cerebral artery, RCP Regional cerebral perfusion. Health Conditions: HRP High risk pregnancy, RDS Respiratory distress syndrome, SCD Sickle cell disease, SDB Sleep disordered breathing, HLHS Hypoplastic left heart syndrome.

Neurocognitive Measures: NBAS Neonatal Behaviour Assessment Scales. BINS Bayleys Infant Neurodevelopmental Screener, BSID Bayley Scales of Infant Development, BSID-II Bayley Scales of Infant Development-II, BSITD-III Bays Scales of Infant and Toddler Development-II BRIEF Behiour Rating Inventory of Executive Functioning, BPS-II Brigance Preschool Screen-II BPVS -I British Picture Vocabulary Scale-II CVLT California Verbal Learning Test for Children, CMS Children's Memory Scale CPT/CPT-II Conners's Continuous Performance Test-II DDST-II Denver Developmental Screening Test, GMDS Griffith's Mental Development Scale LIPS-R Leiter International Peformance Sca Ab Woodcock-Johnson Psycho-Educational Battery, VABS Vineland Adaptive Behaviour Scales. 


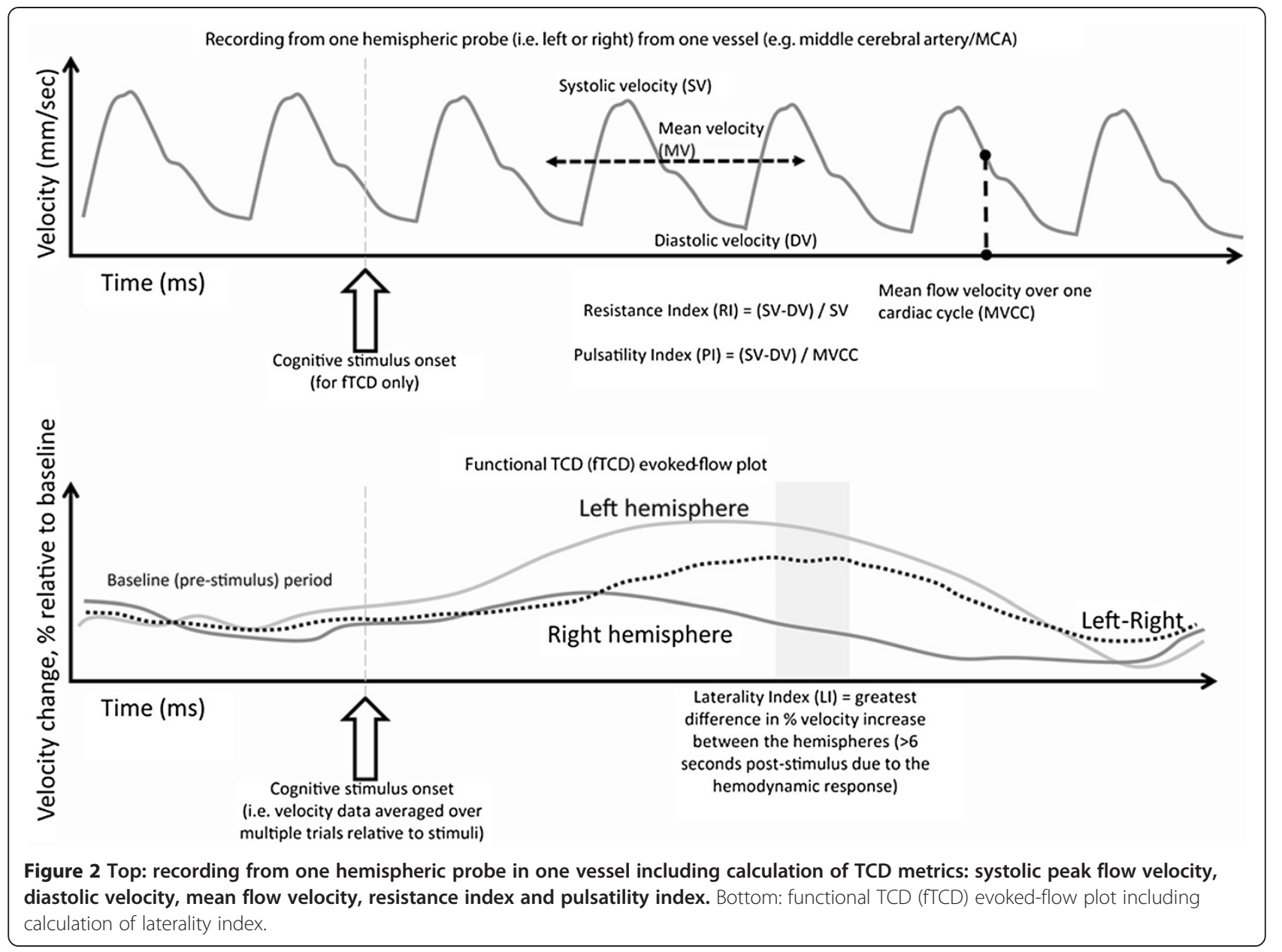

Nineteen (of the 25) papers assessed TCD measures during rest, and six employed fTCD (i.e. changes in velocity relative to a cognitive operation). The vast majority investigated clinical samples (20 of 25): including preterm infants [11-14], infants from high risk pregnancy [15], Sickle cell disease [16-26], autism spectrum disorders [27], and sleep disordered breathing [7]. Most of these studies did not employ a healthy comparison group, instead looking at associations within the clinical group. The remaining studies assessed TCD-cognition relationships (5 of 25 articles) in typically developing children $[2-4,28,29]$.

For resting TCD, a number of measures were used, including mean velocity, systolic velocity, diastolic velocity, pulsatility index and resistance index, typically measured bilaterally from the MCA, ICA or ACA. Less commonly the PCA and BA were assessed. Six articles employing fTCD were included, all measuring bilaterally from the MCA [2-4,27-29]. A broad range of behavioural and cognitive domains were assessed such as the intelligence quotient (IQ; including the Wechsler Intelligence Scale for Children, Wechsler Preschool and Primary Scale of Intelligence and the Woodcock-Johnson Psycho-Educational Battery), neonatal behaviour (e.g. Neonatal Behaviour Assessment Scales), language (e.g. Test of Language DevelopmentPrimary Third Edition and British Picture Vocabulary Scale-II, Test of Word Reading Efficiency), memory (e.g. Children's Memory Scale and the California Verbal Learning Test for Children) and executive function (e.g. Conners's Continuous Performance Test and Trail Making Test). All studies are summarised in Table 1. Major findings are discussed below, relative to clinical (Sickle cell disease and others) and non-clinical child samples.

\section{Children with Sickle cell disease}

There were thirteen studies investigating children with Sickle cell disease, with most reporting an association between high blood flow velocities and impaired cognition, from infanthood to adolescence. Hogan et al. [19] reported that in infants (assessed at nine months) with Sickle cell disease, high blood flow velocities (both systolic velocity and mean velocity in the BA, MCA and ICA) were associated with moderate to high risk of neurodevelopmental delay. Armstrong et al. [30] reported that lower scores in the communications, daily living and socialisation domains of the Vineland Adaptive Behaviour Scales 
were associated with higher systolic velocities, even for velocities within the normal range in infants with Sickle cell disease. Similarly, Schatz et al. [25] reported that preschool-aged children with Sickle cell disease and delayed development had significantly higher MCA mean velocities, compared to healthy controls. Sanchez et al. [24] reported a negative association between MCA systolic velocities and syntactical ability in children with Sickle cell disease. Furthermore, Ruffieux et al. [23] reported an association between abnormally high velocities (maximum velocity $>200 \mathrm{~cm} / \mathrm{sec}$ or peak systolic $>250 \mathrm{~cm} / \mathrm{sec}$ ) and poor memory performance in children with Sickle cell disease.

Kral et al. [22] found that children and adolescents with Sickle cell disease and abnormal systolic velocities (defined as maximum velocity $>200 \mathrm{~cm} / \mathrm{sec}$ in the MCA and ICA) had lower verbal IQ scores than those with conditional/mid-range systolic velocity (defined as maximum velocity $170-200 \mathrm{~cm} / \mathrm{sec}$ ). Children displaying these mid-range systolic velocities performed worse than children with normal systolic velocities (defined as maximum velocity $<170 \mathrm{~cm} / \mathrm{sec}$ ) on measures of sustained attention/concentration and executive function. The conditional systolic velocities group were however the slowest to complete the Trail Making Test. Employing the same sample, Kral and Brown [20] reported that these laboratory measures of cognitive function did not translate to problems with everyday measures of cognition (i.e. academic attainment and grade retention). However, children with abnormally high TCD measures received significantly more special education services [20].

With respect to sample size, the largest study $(n=143)$ included in this review was performed by Bernaudin and colleagues [17] and involved children with Sickle cell disease and non-affected siblings. Children with Sickle cell disease and abnormal TCD (defined as maximum velocity $>200 \mathrm{~cm} / \mathrm{sec}$ in the BA, MCA, ACA, PCA and ICA) had lower cognitive performance than children with Sickle cell disease and normal TCD for Picture Arrangement and Performance IQ (on the WISC-II/WPPSI-R). However, no significant difference was observed after the exclusion of participants with a history of stroke $(n=5)$.

In the only study to report a positive association between blood flow velocity and cognition in a Sickle cell disease sample, Kral et al. [21] reported that after controlling for age and hematocrit, children with Sickle cell disease and high and mid-range systolic velocities had better verbal memory (Children's Memory Scale Stories) compared with children with Sickle cell disease and normal TCD velocities. There were also reports of a lack of association between blood flow velocities and cognition in Sickle cell disease child samples [16,18,26,31]. Onofri et al. [31] found no relationship between IQ (performance and verbal) and systolic velocities in a sample of children with Sickle cell disease. A study by Aygun et al. [16] observed no association between scores on an academic screening test and mean velocities (from multiple vessels). Strouse and colleagues [26], reported no correlation between ACA systolic velocities and IQ in children with Sickle cell disease. Similarly, Hijmans et al. [18] reported no association between mean velocity (MCA, $\mathrm{ACA}$, and ICA) and cognitive measures (including IQ, response inhibition, sustained attention, planning and visuospatial working memory) in children with severe Sickle cell disease. However, children with right greater than left asymmetries in resting mean velocities had better sustained attention [18].

\section{Children with other clinical conditions}

Alatas and colleagues [15] reported that in babies from high-risk pregnancies there was a positive relationship between in-utero MCA pulsatility index and five-minute Apgar scores after delivery, where low pulsatility index was associated with poor physical and neurological health. There was no association in babies from mothers with normal pregnancies.

Three studies were conducted in premature infants $[11,12,14]$. Scherjon et al. [14] reported that in preterm infants without intracranial haemorrhage, there was a relationship between MCA mean velocity ratio (defined as mean velocity in the first 12 hours after birth, divided by mean velocity in the period from 12 hours until 168 hours after birth) and Prechtl score at 40 weeks corrected gestational age; where if MCA mean velocity did not increase after birth, the child was more likely to have a suspected neurological abnormality. They reported no relationships between mean velocity ratio and neurological functioning at six and 12 months [14]. Arditi and colleagues [11] reported that in a group of infants born prematurely with TCD data collected at corrected 37 weeks gestational age: (1) higher right MCA systolic velocities were related to poorer neonatal perceptual performance (on habituation and orientation); (2) higher left MCA systolic velocities were associated with a better Mental Development Index score at 24 months; and (3), those with higher left MCA systolic velocities (as compared to right MCA systolic velocities) had better neonatal orientation and habituation scores as neonates and MDI scores at 24 months. In another study of preterm infants, Ojala and colleagues [12] compared those being ventilated for respiratory distress syndrome (V-RDS) with preterm infants with no signs and not ventilated (N-RDS) using the ACA resistance index. They reported that during the early postnatal transition (the first day of life measured at six, 12 and 24 hours), a lower resistance index was associated with a higher risk of adverse neurologic outcome in the group of N-RDS preterm infants at 12 months of age; this was not the case for the V-RDS infants. 
Rennie et al. [13] found that developmentally delayed infants (defined as a score of $<70$ on the Bayley Scale of Infant Development at age 18 months) did not show the usual steady increase in ACA mean velocity over the first three days of life, as compared to typically developing infants. A rise then a fall in mean velocity occurred in four of nine of the developmentally delayed group (44\%), whereas this pattern occurred in a smaller percentage (four of 31 participants, 13\%) of the group who were subsequently normal.

Bruneau et al. [27] compared children with autistic behaviour, mentally retarded children without autistic symptoms and typically developing controls. In the healthy control group they found that auditory stimulation resulted in increased left MCA mean velocity and decreased left MCA resistance index. This pattern was also observed in the mentally retarded without autistic symptoms group, although the degree of lateralisation was reduced. However, in the autistic group, children displayed a symmetrical decrease of MCA mean velocities and an increase in the resistance index.

Hill and colleagues [7] reported that MCA systolic velocity was significantly higher, processing speed slower, and visual attention poorer, in a group of children with mild sleep disordered breathing as compared to controls. However, these cognitive and TCD measures did not significantly correlate.

\section{Typically developing samples}

Five studies assessed healthy children in order to investigate relationships between fTCD and cognition using visual stimulation [2,3], passive and expressive language tasks [4,29], and (non-) lexical word generation paradigm [28]. A recent study by Groen et al. [3] reported leftlateralized activation for language production and rightlateralized activation for visuospatial memory in the majority of children (58\%). In this study, boys showed a trend for stronger right-hemisphere lateralization for visuospatial memory than girls, but there was no gender effect on language laterality. Children with left-lateralized language production achieved higher standard scores on vocabulary and non-word reading, regardless of the laterality of visuospatial memory. Having language and visuospatial functions in the same hemisphere was not associated with poor cognitive performance [3]. In a previous study, Groen et al. [2] reported a right hemispheric specialization for a visuospatial task in children, however the degree of lateralisation was unrelated to cognitive performance.

Using a sample of right-handed children, Stroobant et al. [32] reported that both receptive and expressive language tasks elicited left hemispheric lateralization which was more pronounced in the expressive task. However, lateralization did not relate to language performance or hand dominance. Similarly, Lohmann et al. [4] reported that a language task induced a left-lateralised velocity increase in children between two and nine years, however this lateralisation was unrelated to language performance. Haag et al. [28] reported that in right-handed children and adolescents, the picture description paradigm failed to indicate left hemispheric dominance in a substantial proportion of the sample regardless of age. However, although Haag et al. [28] measured the effect of a cognitive process on blood flow velocity, they did not correlate changes with a behavioural cognitive measure.

\section{Discussion}

We aimed to systematically review evidence for associations between cognitive performance and cerebrovascular function in children via TCD measures. Generally, high blood flow velocities were associated with poor cognitive performance in child Sickle cell disease samples, and decreased blood flow velocities were associated with poor cognitive outcomes in infants from high risk pregnancies or births. In healthy samples, blood flowvelocity increases were seen during cognitive tasks, with predicted lateralised responses seen for visual and verbal tasks, however these physiological responses did not appear to relate to standardised cognitive measures.

\section{Resting blood flow velocities and cognitive/neurological functioning}

Resting cerebral blood flow velocities such as systolic, diastolic and mean were commonly assessed in relation to cognitive performance $[7,11-14,16-26,30]$. The majority of studies reported an association between blood flow velocity and cognition, with the extremes of systolic and mean blood flow velocities (i.e., very low or very high) being associated with poorer cognitive or neurological functioning. However, six studies reported no associations, including four Sickle cell disease studies [16,18,26,31], one study on preterm infants [12] and one on children with sleep disordered breathing [7]. The interpretation of these studies reporting no association is limited by the lack of information about potential confounders (e.g., medication doses and age), which are required to adequately examine the outcome of cognitive performance in children by means of TCD.

Much of the research reviewed here related to children with Sickle cell disease. Higher systolic and mean velocities were associated with lower IQ or poorer cognitive performance in seven samples of children with Sickle cell disease [17,19,22-25,30], although this effect did not hold in one sample when accounting for a history of stroke [17]. The reported cognitive deficits did not translate into academic achievement impairments, but those with higher systolic velocities did receive more special education services [20]. Conflicting other studies, Kral et al. [21] 
reported that after controlling for age and medication, children with Sickle cell disease and higher systolic velocities displayed better verbal memory performance than those with lower velocities. Four Sickle cell disease studies reported no association between cognitive performance and resting blood flow velocities $[16,18,26,31]$. There have been mixed findings from other brain imaging techniques in Sickle cell samples, for example poor cognitive function has been associated with decreased regional cerebral blood flow as measured using PET [33] and increased cerebral blood flow using fMRI [26].

Clinical studies assessing premature and low birth weight infants showed consistent associations between low blood flow velocities and poor cognitive outcomes. In a study tracking low birth weight infants, Rennie et al. [13] showed how over the first three days of life systolic velocity increased, and that infants with developmental delay at 18 months of age were less likely to show this characteristic increase. In a similar study of premature infants, Scherjon et al. [14] reported that a larger increase in mean velocity in the first days of life related to better neurological functioning at 40 weeks corrected gestational age. Likewise, another study found higher systolic velocities measured at birth were related to lower neonatal habituation performance and neurological functioning at two years [11].

There was some suggestion that asymmetries (i.e., differences between the hemispheres) in resting blood flow velocities were associated with cognitive performance. Greater left than right systolic velocity was related to better neonatal habitation performance and neurological functioning at two years [11]. Further, children with Sickle cell disease had better sustained attention when right mean velocities were greater than the left [18].

\section{Functional TCD measures and cognition/neurological functioning}

The study by Bruneau et al. [27], also mentioned above, reported that blood flow velocities (mean, systolic and diastolic) increased during auditory stimulation in healthy and mentally retarded children, however velocities decreased in a group with autistic behaviours. They suggested that instead of downstream vasodilation in response to cognitive demands, those with autistic behaviours may vasoconstrict [27].

All other fTCD studies were in healthy samples [2-4,28,32]. In all studies a lateralised response during a cognitive operation was observed, with exception of one task (picture description, which was one of two tasks employed, the other being word generation) used by Haag et al. [28]. Stroobant et al. [32] noted that the expressive language task generated a greater lateralisation than the receptive language task. The lateralisation index (i.e., the difference in the degree of blood flow velocity increase between the hemispheres relative to a cognitive operation; see Figure 2) was related to cognitive performance in only one study [3], but not in four studies $[2,4,28,32]$.

\section{Measures of vessel resistance and cognition/neurological functioning}

Measures of vessel resistance such as pulsatility and resistance indexes have shown to relate to cognitive impairment in aged and demented samples [8]. These measures were only assessed in three childhood studies $[12,15,27]$. Low pulsatility index recorded in-utero was related to lower physical and neurological functioning five-minutes post-birth in infants from high risk pregnancies, but not in controls [15]. Similarly, low resistance index taken in the first day of life was related to neurological impairments at 12 months in a group of preterm infants who required ventilation after birth. However this effect was not found in preterm infants not requiring ventilation. It therefore appears that in preterm infants with compromised physical reserve, low cerebrovascular resistance puts them at risk for neurological impairment (at least temporarily).

Bruneau et al. [27] was the only study to assess changes in cerebrovascular resistance in relation to cognitive stimulation. They reported that the resistance index decreased on the left side during auditory stimulation in typically developing children, to a lesser extent in mentally retarded children, but increased in children with autistic behaviours [27].

\section{Limitations and future recommendations}

One limitation of the TCD method is the assumption that artery diameter remains constant, therefore any change in velocity represents a change in flow. It has been reported however, that the diameter of the MCA does not significantly change during moderate alterations in blood pressure [34,35] and therefore any change in velocity reflects change in blood volume through the artery. Notably, and similar to other psychophysiological measurements, the evidence base for the reliability of TCD requires more work. In a recent paper, McDonnell et al. [36] reported that the test-retest reliability (three testing sessions over a few weeks) of the TCD-measured cerebrovascular response (CVR; change in blood flow velocity relative to inhalation of gas with 95\% $\mathrm{O}_{2}$ and $5 \% \mathrm{CO}_{2}$ ) was strong, particularly for measurements taken in sitting as opposed to supine. Sanchez et al. [24] reported elevated systolic velocities apparent in a group of five children with Sickle cell disease remained elevated over a six month period. These studies provide evidence for the reliability of TCD measures however further work is required, particularly in relation to fTCD measures. 
Many studies did not detail the manufacturer of the TCD set-up employed. Specifications vary greatly between different manufacturers, for example sampling rates range from $1 \mathrm{~Hz}$ to $100 \mathrm{~Hz}$. It is unknown if TCD measurements produced are equivalent between commercially available set-ups. Future papers must note the TCD manufacturer and associated recording parameters. Further, simple experimental design elements were often missing in identified studies, such as the time period used to collect resting TCD measures (e.g. 30 seconds, 1 minute or 2 minutes). A concerted effort to include these experimental design factors is required.

A further limitation of this review, and of all reviews of retrospectively published data, is that findings may be biased, with significant associations more likely to be published than non-significant associations [37]. Most studies investigated associations between cognition and TCD measures in Sickle cell disease samples, which limits extrapolation to other clinical as well as healthy populations. Future research therefore needs to focus on non-Sickle Cell disease samples. Further, age and sex effects have been under-investigated [9]. Of the articles reviewed here, one reported stronger right-hemisphere lateralization for visuospatial memory in boys as compared with girls [3]. In terms of assessing age-related change, TCD is particularly well placed to investigate changes in infancy, an age-range where other techniques (such as fMRI) are not feasible. Longitudinal analyses would provide opportunities for tracking the development of lateralisation of function. Recent analyses have shown that the relationship between the lateralisation index from fTCD and handedness are complex [38], deserving further assessment. Finally, neurovascular coupling has been investigated in adults simultaneously recording TCD and electroencephography $[39,40]$. This experimental design could be translated into child samples to investigate neurovascular coupling in healthy and clinical samples, and relationships with cognitive functioning.

Although all studies employed standardised cognitive and behavioural measures, they varied greatly, which made direct comparisons difficult. We were therefore unable to investigate how TCD measures differentially associate with cognitive domains. This would be a good avenue of future research.

\section{Conclusion}

Poor cognitive performance appears to be associated with decreased blood flow velocities in premature infants, and increased velocities in Sickle cell disease children using TCD methods. TCD measures are sensitive to cerebrovascular demand during cognitive processing, with lateralised responses typical of the cognitive domain (i.e. visuospatial right and language left) assessed. There is an increased attention on vascular contributions to cognitive function and impairment, and interactions with neuronal function. TCD is a safe, portable, noninvasive method suitable for measurement of cerebrovascular function in child samples.

\section{Abbreviations}

ACA: Anterior cerebral artery; BA: Basilar artery; MCA: Middle cerebral artery; PCA: Posterior cerebral artery; TCD: Transcranial doppler.

\section{Competing interests}

All authors state no conflict of interest.

\section{Authors' contributions}

HADK conceptualised the study. MJB conducted the search and together with $\mathrm{JH}$ and HADK reviewed abstracts. MJB and HK extracted the data from identified publications. HADK and MJB drafted the manuscript. OFC, NAB, JH and MK revised the manuscript for important intellectual content. All authors read and approved the final manuscript.

\section{Acknowledgements}

HADK is supported by an Australian National Health and Medical Research Council Training Fellowship (568890).

\section{Author details}

${ }^{1}$ Cognitive Neuroscience Laboratory, School of Psychology, Social Work and Social Policy, University of South Australia, GPO BOX 2471, 5001 Adelaide, SA, Australia. ${ }^{2}$ Department of Cognitive Neuroscience, Donders Institute for Brain, Cognition and Behavior, Radboudumc, Nijmegen, The Netherlands. ${ }^{3}$ Brain and Cognition Laboratory, School of Psychology, Flinders University, Adelaide, Australia. ${ }^{4}$ ARC Centre of Excellence in Cognition and its Disorders, Department of Cognitive Science, Macquarie University, Sydney, Australia.

Received: 9 October 2013 Accepted: 26 February 2014

Published: 6 March 2014

\section{References}

1. Lecrux C, Hamel E: The neurovascular unit in brain function and disease. Acta Physiol 2011, 203(1):47-59.

2. Groen MA, Whitehouse AJ, Badcock NA, Bishop DV: Where were those rabbits? A new paradigm to determine cerebral lateralisation of visuospatial memory function in children. Neuropsychologia 2011, 49(12):3265-3271.

3. Groen MA, Whitehouse AJO, Badcock NA, Bishop DVM: Does cerebral lateralization develop? A study using functional transcranial Doppler ultrasound assessing lateralization for language production and visuospatial memory. Brain Behav 2012, 2(3):256-269.

4. Lohmann H, Drager B, Muller-Ehrenberg S, Deppe M, Knecht S: Language lateralization in young children assessed by functional transcranial Doppler sonography. Neuroimage 2005, 24(3):780-790.

5. Lohmann H, Ringelstein EB, Knecht S: Functional transcranial Doppler sonography. Front Neurol Neurosci 2006, 21:251-260.

6. Bishop DV, Badcock NA, Holt G: Assessment of cerebral lateralization in children using functional transcranial Doppler ultrasound (fTCD). J Vis Exp 2010, (43). doi:10.3791/2161.

7. Hill CM, Hogan AM, Onugha N, Harrison D, Cooper S, McGrigor VJ, Datta A Kirkham FJ: Increased cerebral blood flow velocity in children with mild sleep-disordered breathing: a possible association with abnormal neuropsychological function. Pediatrics 2006, 118(4):e1100-e1108.

8. Keage HAD, Churches OF, Kohler M, Pomeroy D, Luppino R, Bartolo ML, Elliott S: Cerebrovascular Function in Aging and Dementia: A Systematic Review of Transcranial Doppler Studies. Dement Geriatr Cogn Dis Extra 2012, 2(1):258-270.

9. Stroobant N, Vingerhoets G: Transcranial Doppler ultrasonography monitoring of cerebral hemodynamics during performance of cognitive tasks: a review. Neuropsychol Rev 2000, 10(4):213-231.

10. Moher D, Liberati A, Tetzlaff J, Altman DG, Group P: Preferred reporting items for systematic reviews and meta-analyses: the PRISMA statement. J Clin Epidemiol 2009, 62(10):1006-1012. 
11. Arditi H, Feldman R, Hammerman C, Eidelman Al: Cerebral blood flow velocity asymmetry, neurobehavioral maturation, and the cognitive development of premature infants across the first two years. J Dev Behav Pediatr 2007, 28(5):362-368.

12. Ojala T, Kaapa P, Helenius H, Ekblad U, Kero P, Valimaki I, Aarimaa T: Low cerebral blood flow resistance in nonventilated preterm infants predicts poor neurologic outcome. Pediatr Crit Care Med 2004, 5(3):264-268.

13. Rennie JM, Coughtrey H, Morley R, Evans DH: Comparison of cerebral blood flow velocity estimation with cranial ultrasound imaging for early prediction of outcome in preterm infants. J Clin Ultrasound 1995, 23(1):27-31.

14. Scherjon SA, Smolders-DeHaas H, Oosting H, Kok JH, Zondervan HA: Neonatal cerebral circulation in relation to neurosonography and neurological outcome: a pulsed Doppler study. Neuropediatrics 1994, 25(4):208-213.

15. Alatas C, Aksoy E, Akarsu C, Yakin K, Bahceci M: Prediction of perinatal outcome by middle cerebral artery Doppler velocimetry. Arch Gynecol Obstet 1996, 258(3):141-146.

16. Aygun B, Parker J, Freeman MB, Stephens AL, Smeltzer MP, Wu S, Hankins JS, Wang WC: Neurocognitive screening with the Brigance preschool screen-II in 3-year-old children with sickle cell disease. Pediatr Blood Cancer 2011, 56(4):620-624.

17. Bernaudin F, Verlhac S, Fréard F, Roudot-Thoraval F, Benkerrou M, Thuret I, Mardini R, Vannier JP, Ploix E, Romero M, Cassé-Perrot C, Helly M, Gillard E, Sebag G, Kchouk H, Pracros JP, Finck B, Dacher JN, Ickowicz V, Raybaud C, Poncet $\mathrm{M}$, Lesprit $\mathrm{E}$, Reinert $\mathrm{PH}$, Brugières $\mathrm{P}$ : Multicenter prospective study of children with sickle cell disease: radiographic and psychometric correlation. J Child Neurol 2000, 15(5):333-343.

18. Hijmans CT, Grootenhuis MA, Oosterlaan J, Heijboer H, Peters M, Fijnvandraat K: Neurocognitive deficits in children with sickle cell disease are associated with the severity of anemia. Pediatr Blood Cancer 2011, 57(2):297-302.

19. Hogan AM, Kirkham FJ, Prengler M, Telfer P, Lane R, Vargha-Khadem F, Haan M: An exploratory study of physiological correlates of neurodevelopmental delay in infants with sickle cell anaemia. Br J Haematol 2006, 132(1):99-107.

20. Kral MC, Brown RT: Transcranial Doppler ultrasonography and executive dysfunction in children with sickle cell disease. J Pediatr Psychol 2004, 29(3):185-195.

21. Kral MC, Brown RT, Connelly M, Cure JK, Besenski N, Jackson SM, Abboud MR: Radiographic predictors of neurocognitive functioning in pediatric Sickle Cell disease. J Child Neurol 2006, 21(1):37-44.

22. Kral MC, Brown RT, Nietert PJ, Abboud MR, Jackson SM, Hynd GW: Transcranial Doppler ultrasonography and neurocognitive functioning in children with sickle cell disease. Pediatrics 2003, 112(2):324-331.

23. Ruffieux N, Njamnshi AK, Wonkam A, Hauert CA, Chanal J, Verdon V, Fonsah JY, Eta SC, Doh RF, Ngamaleu RN, Kengne AM, Fossati C, Sztajzel R: Association between biological markers of sickle cell disease and cognitive functioning amongst Cameroonian children. Child Neuropsychol 2013, 19(2):143-160.

24. Sanchez CE, Schatz J, Roberts CW: Cerebral blood flow velocity and language functioning in pediatric sickle cell disease. J Int Neuropsychol Soc 2010, 16(2):326-334.

25. Schatz J, McClellan CB, Puffer ES, Johnson K, Roberts CW: Neurodevelopmental screening in toddlers and early preschoolers with sickle cell disease. J Child Neurol 2008, 23(1):44-50.

26. Strouse JJ, Cox CS, Melhem ER, Lu H, Kraut MA, Razumovsky A, Yohay K, van Zij PC, Casella JF: Inverse correlation between cerebral blood flow measured by continuous arterial spin-labeling (CASL) MRI and neurocognitive function in children with sickle cell anemia (SCA). Blood 2006, 108(1):379-381.

27. Bruneau N, Dourneau MC, Garreau B, Pourcelot L, Lelord G: Blood flow response to auditory stimulations in normal, mentally retarded, and autistic children: a preliminary transcranial Doppler ultrasonographic study of the middle cerebral arteries. Biol Psychiatry 1992, 32(8):691-699.

28. Haag A, Moeller N, Knake S, Hermsen A, Oertel WH, Rosenow F, Hamer HM: Language lateralization in children using functional transcranial Doppler sonography. Dev Med Child Neurol 2010, 52(4):331-336.

29. Stroobant N, Buijs D, Vingerhoets G: Variation in brain lateralization during various language tasks: a functional transcranial Doppler study. Behav Brain Res 2009, 199(2):190-196.

30. Armstrong FD, Elkin TD, Brown RC, Glass P, Rana S, Casella JF, Kalpatthi RV, Pavlakis S, Mi Z, Wang WC: Developmental function in toddlers with sickle cell anemia. Pediatrics 2013, 131(2):e406-e414
31. Onofri A, Montanaro M, Rampazzo P, Colombatti R, Farina FM, Manara R, Sainati L, Ermani M, Baracchini C, Meneghetti G: Intellectual impairment and TCD evaluation in children with sickle cell disease and silent stroke. Perspect Med 2012, 1(1-12):272-274.

32. Stroobant N, Van Boxstael J, Vingerhoets G: Language lateralization in children: a functional transcranial Doppler reliability study. J Neurolinguistics 2011, 24(1):14-24.

33. Powars DR, Conti PS, Wong WY, Groncy P, Hyman C, Smith E, Ewing N, Keenan RN, Zee CS, Harold Y, Hiti AL, Teng EL, Chan LS: Cerebral vasculopathy in sickle cell anemia: diagnostic contribution of positron emission tomography. Blood 1999, 93(1):71-79.

34. Giller CA, Bowman G, Dyer H, Mootz L, Krippner W: Cerebral Arterial Diameters during Changes in Blood Pressure and Carbon Dioxide during Craniotomy. Neurosurgery 1993, 32(5):737-742.

35. Serrador JM, Picot PA, Rutt BK, Shoemaker JK, Bondar RL: MRI Measures of Middle Cerebral Artery Diameter in Conscious Humans During Simulated Orthostasis. Stroke 2000, 31(7):1672-1678.

36. McDonnell MN, Berry NM, Cutting MA, Keage HA, Buckley JD, Howe PR: Transcranial Doppler ultrasound to assess cerebrovascular reactivity: reliability, reproducibility and effect of posture. Peer J 2013, 1:e65.

37. Easterbrook PJ, Gopalan R, Berlin JA, Matthews DR: Publication bias in clinical research. Lancet 1991, 337(8746):867-872.

38. Groen MA, Whitehouse AJO, Badcock NA, Bishop DVM: Associations between Handedness and Cerebral Lateralisation for Language: A Comparison of Three Measures in Children. PLoS One 2013, 8(5):e64876.

39. Rosengarten B, Aldinger C, Spiller A, Kaps M: Neurovascular Coupling Remains Unaffected During Normal Aging. J Neuroimaging 2003, 13(1):43-47.

40. Rosengarten B, Kaps M: A Simultaneous EEG and Transcranial Doppler Technique to Investigate the Neurovascular Coupling in the Human Visual Cortex. Cerebrovasc Dis 2010, 29(3):211-216.

doi:10.1186/1471-2377-14-43

Cite this article as: Bakker et al:: Cerebrovascular function and cognition in childhood: a systematic review of transcranial doppler studies. BMC Neurology 2014 14:43

\section{Submit your next manuscript to BioMed Central and take full advantage of:}

- Convenient online submission

- Thorough peer review

- No space constraints or color figure charges

- Immediate publication on acceptance

- Inclusion in PubMed, CAS, Scopus and Google Scholar

- Research which is freely available for redistribution 